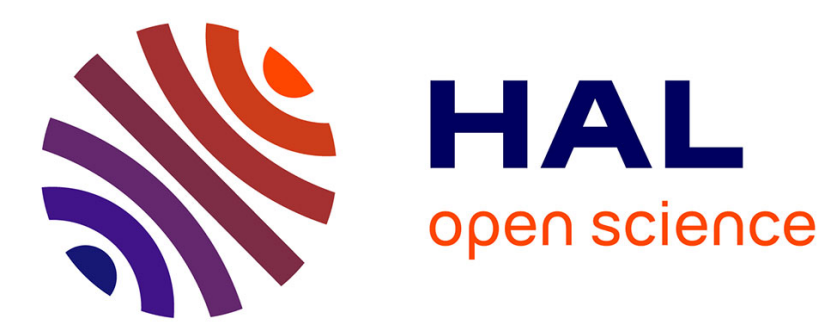

\title{
If Not Computers Then What? Returns to Computer Use in the UK Revisited
}

\author{
Alan Marin, Reza Arabsheibani
}

\section{To cite this version:}

Alan Marin, Reza Arabsheibani. If Not Computers Then What? Returns to Computer Use in the UK Revisited. Applied Economics, 2006, 38 (21), pp.2461-2467. 10.1080/00036840500427668 . hal00581913

\section{HAL Id: hal-00581913 \\ https://hal.science/hal-00581913}

Submitted on 1 Apr 2011

HAL is a multi-disciplinary open access archive for the deposit and dissemination of scientific research documents, whether they are published or not. The documents may come from teaching and research institutions in France or abroad, or from public or private research centers.
L'archive ouverte pluridisciplinaire HAL, est destinée au dépôt et à la diffusion de documents scientifiques de niveau recherche, publiés ou non, émanant des établissements d'enseignement et de recherche français ou étrangers, des laboratoires publics ou privés. 


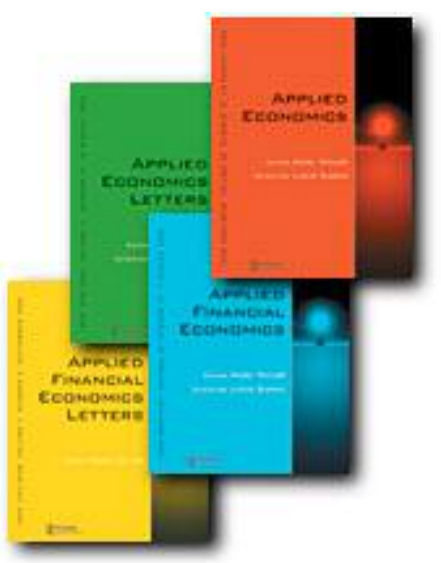

If Not Computers Then What? Returns to Computer Use in the UK Revisited

\begin{tabular}{|c|c|}
\hline Journal: & Applied Economics \\
\hline Manuscript ID: & APE-05-0103 \\
\hline Journal Selection: & Applied Economics \\
\hline $\begin{array}{r}\text { Date Submitted by the } \\
\text { Author: }\end{array}$ & 22-Feb-2005 \\
\hline JEL Code: & $\begin{array}{l}\text { D24 - Production|Capital and Total Factor Productivity|Capacity }< \\
\text { D2 - Production and Organizations < D - Microeconomics, J24 - } \\
\text { Human Capital|Skills|Occupational Choice|Labor Productivity }<\text { J2 } \\
\text { Time Allocation, Work Behavior, and Employment Determination } \\
\text { and Creation < J - Labor and Demographic Economics, J31 - Wage } \\
\text { Level and Structure|Wage Differentials by Skill, Training, } \\
\text { Occupation, etc. < J3 - Wages, Compensation, and Labor Costs < J } \\
\text { - Labor and Demographic Economics }\end{array}$ \\
\hline Keywords: & Computers, Wages, Productivity \\
\hline
\end{tabular}

\section{Manuscript Central ${ }^{\text {TH}}$}




\title{
IF NOT COMPUTERS THEN WHAT? RETURNS TO COMPUTER USE IN THE UK REVISITED*.
}

\author{
G. Reza Arabsheibani, \\ Department of Economics \\ University of Wales Swansea \\ James Callaghan Building \\ Singleton Park, \\ Swansea SA2 8PP \\ and \\ Alan Marin, \\ Department of Economics \\ London School of Economics \\ Houghton Street, \\ London WC2A 2AE
}

\begin{abstract}
In recent years much attention has been paid to the effect on wages of skill-biased technology, especially the use of computers. Although empirical studies have shown a positive relationship between computer-use and earnings, doubts have been cast on whether this is a causal relationship or merely represents unobserved other factors, which are themselves positively linked to computer usage. In this paper we provide evidence that computers themselves raise wages. Although their impact on wages falls as other controls are included in the regression, it still remains significant whilst the effect of another proxy for unobserved factors becomes insignificant. Furthermore, improvements in computer use have an additional impact on earnings, supporting the productivity interpretation.
\end{abstract}

\footnotetext{
*Acknowledgments: We would like to thank Leon Feinstein for help and advice with the data and Jonathan Wadsworth for his comments on the paper. We are also grateful to the ESRC Archive, Peter Shepherd and Centre for Longitudinal Studies for the use of the National Child Development Study.
} 


\section{Introduction}

Since the early 1970 's, despite the fact that supply of skilled labour relative to unskilled labour has risen, thereby making unskilled labour scarcer, wage inequality has dramatically risen in the US. For example, the premium for the male college educated workers relative to high school educated workers rose from $30 \%$ in 1979 to about $70 \%$ in 1995 (Blanchflower and Slaughter, 1999). The UK has also experienced a rapid rise in inequality (Schmitt, 1994; Gosling and Meghir, 1994), while some other OECD countries have experienced a similar rise albeit at a much slower rate (for a comparison see Blanchflower and Slaughter, 1998, Table 1).

While the facts speak for themselves, the reason(s) for such a pronounced rise in inequality is far from settled. There are, however, a number of explanations that have been proposed. Although other suggestions, such as de-unionization and deindustrialization have been put forward, the two main competing theories are the impact of international trade, via the Stolper-Samuelson effect, and the impact of skill-biased technology. It is the latter view that has attracted much of attention from labour economists. The argument, in this case, is that this type of technology tends to increase the productivity of skilled rather than unskilled workers and hence increases the wage of the more skilled relative to the less skilled, thereby increasing wage inequality (Bound and Johnson, 1992; Katz and Murphy, 1992; Berman, Bound, and Machin, 1998; Machin and Van Reenen, 1998; Haskel and Slaughter, 2001). 
In attempting to test for the impact of new (skill-biased) technology on wages Krueger (1993), using US data, demonstrated that those who use computers at work have $24.6 \%$ wage advantage in 1994 and $37.4 \%$ wage advantage in 1989, compared to workers who do not use computers.

Since the important analysis of Krueger a number of studies, mostly for countries other than the US (but see Autor, Katz and Krueger, 1998, for the US), have emerged confirming the significant and positive impact of computer use on wages. Reilly (1995) found a 13.5\% advantage for Canada; Arabsheibani, Emami and Marin (2004) found a 23\% advantage in 1985 and a 20\% advantage in 1990 for the UK; DiNardo and Pischke (1997) found a 17\% advantage for Germany in 1991; Miller and Mulvey's (1997) results show an advantage of $10-15 \%$, depending on the specification of the earnings function, for Australia in 1993; Oosterbeek estimated an $11 \%$ advantage for the Netherlands in 1993; Morrissette and Drolet (1998) found a 14\% advantage for Canada in 1994 and Entorf and Kramarz (1997) found an advantage of around 10\% for a pooled sample of three separate years in the 1980's for France.

\footnotetext{
Although all the above studies confirm the Krueger results a number of authors argue against Krueger's reasoning that computers increase productivity and that is why they have a positive impact on pay. The main argument is that the computer use variable is picking up the effect of unobserved heterogeneity. Reilly, for example, shows that when firm size variables are included in the wage regression the computer use variable becomes insignificant. This follows Hammermesh's (1980) claim that employer size represents 
unobserved differences in human capital between establishments. Arabsheibani et al (2003), however, show that, at least in the case of the UK, the computer use variable is robust to the inclusion of a wide set of variables, including employer size.

In a study damaging to the proponents of the view that there is a productivity effect of computers, DiNardo and Pischke (1997) argue that Krueger's study is an attempt to uncover the "treatment" effect of computer usage. The treatment effect would be the effect on wages if we choose a worker, at random, who does not use a computer at work and place him/her in an identical job with a computer. In other words it is the change in a worker's wage if we assigned at random a number of computers to non-users. Given the shortcomings of cross-section studies, and particularly in the absence of instruments for computer use (or computer knowledge), DiNardo and Pischke resort to using indirect evidence. They find that using pencils or pens at work also has a positive and significant effect on wages and consequently they argue that since pencils are used by around $65 \%$ of the sample, therefore their use cannot signify a scarce skill. In general, we do not expect pencils to raise productivity. DiNardo and Pischke propose that pencils have a positive effect on wages because they are used by workers who would be highly paid anyway. If this argument is true for pencils then the same could be said about computers. Given that $65 \%$ of their sample use pencils, this claim is not as strong as it seems at first sight since it would be stating that $65 \%$ of the workers are likely to be highly paid.

Using a very similar approach for Canada, Morissette and Drolet (1998) show that using fax machines positively and significantly affects earnings and that it yields a higher return 
compared to computers. They, therefore, agree with DiNardo and Pischke, in that computers and fax machines are simply picking up the unobserved differences between workers and jobs.

Entorf and Kramarz (1997), using French data, show that more able workers use computers but those workers also become more productive. This implies that the effect of computers on wages is a combination of the unobserved ability of workers and the productivity enhancing effect of the technology itself. One problem with this study may be driving the results. Their measure of income is discrete and given at monthly level. If hours worked are different between workers, especially for those who use new technologies compared to those who do not, then these will be captured by the variable representing computer use.

Similarly to most other researchers, we neither have access to panel data that includes information on computer use, nor are we able to experiment directly with the treatment effect. In this paper, therefore, we also rely on indirect information to shed more light on the productivity augmenting effect of computers. Our results indicate that, after controlling for ability, for using tools and for improvements in computer use, computer use still positively and significantly determines pay. We interpret these results as favouring the productivity augmenting argument for computer use. 


\section{The Data}

The data used in this paper comes from Sweep V of the National Child Development Study (NCDS). The NCDS comprises all the children born in the UK during the first week of March 1958 (March $3^{\text {rd }}$ to March $9^{\text {th }}$ ). This is an advantage because we do not need to worry about cohort effects. Subsequently, information on these individuals was obtained when they were aged $7,11,16,23$ and finally at the age of 33 in the last available sweep. In the earlier sweeps parents, teachers and others were also surveyed. The survey for Sweep V was carried out in 1991. This last sweep is the only one containing information on using computers at work.

The data set contains, among other things, the standard cross-section information on education, region, race, sex, marital status, and job related characteristics such as tenure, occupation, industry, firm size, sector of employment, union membership and working full time. It also possible to link to the data in the earlier sweeps for the same individuals. This allows us to include two very important variables for our purposes. These are the results of a reading test at the age of seven, $R 7$, and a mathematics test at the age of 7 , M7. These two variables are used to control directly for ability differences between individuals. Although we also have access to test results at a later age, we use the tests at age seven in order to minimize the effects of the education system on performance in aptitude tests. The sample used included all employees. 
Our computer use variable is constructed from the following question:

"In your work do you ever use a computer or word processor with a TV type screen (usually known as VDU)?”

In addition the survey provides information on using tools at work. We regard tools as what could be called an "anti-pencil" measure (the term "anti" as in "anti-matter"), in the sense that tools are usually used more by blue collar (manual) workers. Hence, in a DiNardo and Pischke world, we would expect a negative impact of tools on wages since they represent lower paid workers. Our dependent variable is the natural logarithm of hourly gross wage. Table 1 presents the sample means and standard deviations for the whole sample and for the computer user and non-computer user groups separately.

(Table 1 Here)

Overall $59 \%$ of the sample use computers at work, significantly higher than in the sample used for our previous findings, where the percentage was $41 \%$ in 1990 . (However, that sample, The British Social Attitudes survey, covered all ages in the labour force, and the average age of the computer users was below that of those who did not use computers. As stated earlier, all of the sample in the current study were aged 33, and it thus omits the older workers who were less likely to use computers.) For a number of variables the user and non-user groups have similar means. However, there are interesting differences between the two groups. On average, the computer users earn $£ 2.56$ more per hour and have over 1.3 years more tenure. Even more interestingly, they have higher ability as measured by both of our ability measures. Their average mathematics score at the age of 7 is 59.44 as compared to 48.67 for the non-users (the mathematics score is out of 80 ). Their average reading score at the age of 7 is 85.68 compared to 75.33 for the non-users 
(the reading score is out of 100). With respect to self-assessed ability to write well (Writegood) and to speak well (Speakgood) they also score about 20-30\% higher. These differences indicate that the regression results presented in studies quoted above may suffer from (ability) bias and that it is extremely important to include measures of ability in the relevant regressions.

Other important differences can be seen in education, firm size and full-time employment. On average, computer users are more highly qualified. For example, $22 \%$ of the users have a Degree compared to $5 \%$ of the non-users, whist only $1 \%$ have no qualification compared to $11 \%$ of the non-users. They tend to be working for larger firms: $26 \%$ of users work for firms of above 500 worker size compared to $17 \%$ of non-users, whilst $10 \%$ work for firms with 10 or less workers compared to $20 \%$ of the non-users. $87 \%$ of the users work full-time compared to $69 \%$ of the non-users. Of those who use computers, $76 \%$ indicated that they have got better at using them during the past ten years.

\section{Empirical Results}

Table 2 presents the results of our wage equations. Computer is the dummy representing our computer-use variable. It takes the value of 1 if an individual uses computers at work and zero otherwise. A wide set of other variables including education and ability variables $(R 7, M 7)$, are also included to control for other differences between individuals. Column 1, therefore, presents the results of running the following equation: 


$$
\text { ln Hourly } \text { Wage }_{i}=X_{i} \beta+\gamma \text { Computer }_{i}+u_{i}
$$

Where $X_{i}$ is a vector of characteristics, $\beta$ is the corresponding vector of coefficients, $\gamma$ is the wage premium associated with computer use and $u_{i}$ is the error term.

(Table 2 Here)

\begin{abstract}
The results indicate that the coefficient of Computer is highly significant and positive. To calculate the return to computer use, since our computer variable is a zero-one dummy, we follow a method suggested by Halvorsen and Palmquist (1980). The estimated coefficient implies a return to computer use of $100\left(\mathrm{e}^{0.175}-1\right)$ or $19.1 \%$. This is similar to our previous estimates for the UK, which were just over $20 \%$ for 1985 and 1990 (even though the previous estimates were based on a different sample and a different set of variables).
\end{abstract}

Column 2 of Table 2 presents the results of expanding equation 1 by introducing into the regression the variable which measures using tools at work (Tools), and running a regression of the following form:

$$
\text { ln Hourly } \text { Wage }_{i}=X_{i} \beta+\gamma \text { Computer }_{i}+\psi \text { Tools }_{i}+v_{i}
$$

The coefficient of Tools, $\psi$, as expected, is negative and significant indicating a wage disadvantage of $3.6 \%$ for tool users at work while the computer advantage falls very 
slightly to $18.7 \%$. At this stage our results are consistent with DiNardo and Pischke's results.

Column 3 presents the results of the first of our pieces of indirect evidence on the productivity effects of computers. In this case we use the answer to the following question:

"In the last 10 years have you got better in using a computer to solve problems or give information?"

We construct a dummy variable, Compbtr, to indicate if the individual has got better in using computers (Compbtr=1 if the individual got better and zero otherwise). If computers do not, in themselves, increase productivity, then getting better at using them should not matter. It is the mere fact of using them which is important as a proxy for unobserved inherent ability. As shown in column 3, the coefficient of Compbtr is highly significant and positive, indicating that getting better in computer use, representing an improvement in computer skills and productivity, is rewarded in the labour market.

Our second piece of evidence is presented in column 4. Here we include job specific variables and run the regression in the following form:

$\ln$ Hourly Wage $_{\mathrm{i}}=\mathrm{X}_{\mathrm{i}} \beta+\gamma$ Computer $_{\mathrm{i}}+\psi$ Tools $_{\mathrm{i}}+\sum_{j=1}^{n} \eta_{\mathrm{j}}$ Occupation $_{\mathrm{ij}}+\sum_{k=1}^{m} \phi_{\mathrm{k}}$ Fsize $_{\mathrm{ik}}$ $+\sum_{s=1}^{l} \tau_{\mathrm{s}}$ Industry $_{\mathrm{is}}+\varepsilon_{\mathrm{i}}$ 
where Fsize is a set of dummies representing the size of the establishment, Occupation is a set of dummy variables representing the occupation of the individual and Industry is a set of dummies representing the industry in which the individual works. If the Reilly results applied then we would expect Computer to become insignificant when firm size is entered into the regression. In a DiNardo and Pischke world we would expect Computer and Tools to be affected in similar ways, particularly when occupations are entered into the regression. Our results, however, are different to both of the above studies. Using computers and getting better at using them are still rewarded. The coefficients of both variables do fall indicating that previous regressions were suffering from omitted variable bias, but they remain positive and significant. It seems that in the absence of controlling for industry, occupation and firm size, Computer picks up some of their effects on wages. After such controls are accounted for, Computer still shows a direct and significantly positive effect, a result that points strongly towards the productivity explanation. Tools, on the other hand, is no longer significant. It is difficult at this stage to put forward a convincing case that Tools no longer represents unobserved heterogeneity but Computer still does.

Our last piece of evidence is presented in column 5. In this case we use answers to the question:

"On the days that you were using computers, how many hours do you typically spend in front of it with the screen switched on?"

We construct a variable, Intensity, which is the answer to the above question divided by the respondent's typical working hours per day. This variable, which measures the 
proportion of working hours spent on computers, is designed to indicate the intensity of computer use. Those who do not use computers at work have a zero value for Intensity. Again we propose that if computers do not matter in themselves, then the intensity of their use should not matter. The coefficient for Intensity is positive and significant, again lending support to the productivity argument. This result, however, should be interpreted with more caution than the other results presented. Firstly, it is possible that Intensity may be picking up finer distinctions between occupations. More importantly, the hours of having a screen switched on does not necessarily imply hours of use. If this is true, then it is likely that the Intensity measure overestimates actual computer use and hence its coefficient may be biased. However, the result here is opposite to Oosterbeek's, who finds, using a similar idea but a different measure of intensity, that the more intensive use of computers does not matter in the Netherlands.

We have also re-estimated the regressions for full-time workers only. The results are shown in Table 3. Although there are, inevitably, some small differences in estimated coefficients, all the conclusions are robust with respect to the exclusion of the part-timers.

\section{(Table 3 Here)}

\section{Conclusions}

In this paper we consider the question of whether computers raise the productivity of those who use them. Although using cross-section data to answer such a question is not free of problems, we present evidence that points towards the productivity enhancing role of computers. It is not merely using computers that matter, in terms of obtaining 
additional earnings, but getting better at using them also matters even after a whole set of other controls are entered in the regression. On the other hand there is no remaining effect for using tools on the job once the other controls are introduced.

\begin{abstract}
We cannot, and would not, claim that we have accounted for all of the conceivably possible unobserved heterogeneity which could affect the higher wages associated with computer use. A different type of data or experiment is required for that. However, we do propose that, given our results, there is strong evidence in support of the productivity augmenting role of new technology.
\end{abstract}




\section{References}

Arabsheibani, G.R., J.M. Emami and A. Marin (2004) "The Impact of Computer Use on Earnings in the UK". The Scottish Journal of Political Economy, 51, pp. 82-94.

Autor, D., L.F. Katz and A. Krueger (1998) “Computing Inequality: Have Computers Changed the Labour Market?”. Quarterly Journal of Economics, CXIII, pp.1169-1213.

Berman, E., J. Bound and S. Machin (1998) "Implication of Skill-Biased Technological Change: International Evidence. Quarterly Journal of Economics, CXIII, pp. 1245-79.

Blanchflower, D. and M. Slaughter (1999) "The Causes and Consequences of the Changing Income Inequality: W(h)ither the Debate?’. In A. Fishlow and K. Parker (eds) Growing Apart: The Causes and Consequenses of Global Wage Inequality. (New York: Council on Foreign Relations).

Bound, J. and G. Johnson (1992) “Changes in the Structure of Wages in the 1980's: An Evaluation of Alternative Explanations". American Economic Review, 82, pp. 371-392.

DiNardo, J.E. and J-S Pischke (1997) “The Returns to Computer Use Revisited: Have Pencils Changes the Wage Structure Too?". Quarterly Journal of Economics, February, pp. 291-307. 
Entorf, H. and F. Kramarz (1997) “Does Unmeasured Ability Explain the Higher Wages of the New Technology Workers?". European Economic Review, 41, pp. 1489-1509.

Gosling, A. and C. Meghir (1994) “What Happened to Men's Wages Since the Mid 1960's?”. Fiscal Studies, 15(4), pp. 63-87.

Halvorsen, R. and R. Palmquist (1980) "The Interpretation of Dummy Variables in Semilogarithmic Equations", American Economic Review, vol. 70 (3), pp. 474-475.

Hammermesh, D.S. (1980) "Commentary" in J.J. Sigfield (ed.) Economics of the Firm Size, Market Structure and Social Performance, Washington D.C.: Federal Trade Commission, pp. 383-388.

Haskel, J.E. and M.J. Slaughter (2001) "Does the Sector Bias of the Skill Biased Technical Change Explain Changing Skill Premia?’. Unpublished.

Katz, L.F. and K. Murphy (1992) "Changes in the Relative Wages, 1963-1987: Supply and Demand Factors". Quarterly Journal of Economics, 107, pp. 35-78.

Krueger, A. (1993) "How Computers are Changing the Wage Structure: Evidence from the Microdata 1984-89”. Quarterly Journal of Economics, 108, pp. 33-60. 
Machin, S. and J. Van Reenen (1997) "Technology and Changes in Skill Structure: Evidence from Seven OECD Countries. Quarterly Journal of Economics, CXIII, pp. 1215-44.

Miller, P. and C. Mulvey (1997) "Computer Skills and Wages" Australian Economic Papers, vol. 36, pp. 106-113.

Morrissette, R. and M. Drolet (1998) “Computers, Fax Machines and Wages in Canada: What Really Matters?". Working Paper No. 126, Statistics Canada.

Oosterbeek, H. (1997) "Returns from Computer Use: A Simple Test on the Productivity Interpretations". Economics Letters, 55, pp. 273-277.

Reilly, K.T. (1995) "Human Capital and Information: Employer Size Wage Effects", Journal of Human Resources, 30 (1), pp. 1-18.

Schmitt, J. (1994) “The Changing Structure of Male Earnings in Britain: 1974-88”. In R. Freeman and L. Katz (eds.) Difference and Changes in Wage Structure. Chicago: Chicago University Press and NBER. 
Table 1. Means (and Standard Deviations) of Selected Characteristics of the Sample.

\begin{tabular}{llll}
\hline Variables & All Sample & Computer Users & Non-users \\
\hline Hourly Gross Wage & $£ 6.93(3.78)$ & $£ 7.98(4.05)$ & $£ 5.42(2.72)$ \\
Male & $0.55(0.008)$ & $0.57(0.011)$ & $0.52(0.013)$ \\
Married & $0.71(0.008)$ & $0.71(0.010)$ & $0.72(0.012)$ \\
Tenure & $6.71(5.51)$ & $7.26(5.59)$ & $5.93(5.29)$ \\
M7 & $55.01(24.11)$ & $59.44(23.11)$ & $48.67(24.09)$ \\
R7 & $81.42(21.14)$ & $85.68(18.23)$ & $75.33(23.42)$ \\
White & $0.99(0.002)$ & $0.99(0.002)$ & $0.99(0.003)$ \\
Computer & $0.59(0.008)$ & $1.00(0.00)$ & $0.00(0.00)$ \\
Tools & $0.54(0.008)$ & $0.48(0.011)$ & $0.63(0.013)$ \\
Compbtr & $0.45(0.008)$ & $0.76(0.009)$ & $0.00(0.00)$ \\
Intensity & $0.18(0.30)$ & $0.31(0.34)$ & $0.00(0.00)$ \\
Speakgood & $0.53(0.008)$ & $0.57(0.011)$ & $0.47(0.013)$ \\
Writegood & $0.52(0.008)$ & $0.57(0.011)$ & $0.43(0.013)$ \\
Fulltime & $0.79(0.007)$ & $0.87(0.007)$ & $0.69(0.012)$ \\
No Qualification & $0.05(0.004)$ & $0.01(0.002)$ & $0.11(0.008)$ \\
Lower Vocational & $0.24(0.007)$ & $0.23(0.009)$ & $0.25(0.011)$ \\
Middle Vocational & $0.20(0.007)$ & $0.18(0.008)$ & $0.21(0.011)$ \\
“A” Level & $0.06(0.004)$ & $0.08(0.006)$ & $0.03(0.004)$ \\
Higher Vocational & $0.18(0.006)$ & $0.20(0.009)$ & $0.14(0.009)$ \\
Degree & $0.15(0.006)$ & $0.22(0.009)$ & $0.05(0.006)$ \\
Other Qualification & $0.12(0.005)$ & $0.06(0.005)$ & $0.19(0.010)$ \\
Firm Size (0-10) & $0.14(0.006)$ & $0.10(0.007)$ & $0.20(0.010)$ \\
Firm Size (11-25) & $0.15(0.006)$ & $0.13(0.008)$ & $0.18(0.010)$ \\
Firm Size (26-99) & $0.25(0.007)$ & $0.25(0.009)$ & $0.24(0.011)$ \\
Firm Size (100-499) & $0.24(0.007)$ & $0.26(0.010)$ & $0.21(0.011)$ \\
Firm Size (500+) & $0.22(0.007)$ & $0.26(0.010)$ & $0.17(0.010)$ \\
\hline & & & \\
N & 3572 & 2103 & 1469 \\
\hline
\end{tabular}

Note: The standard deviations of the $0-1$ dummy variables are calculated from the expression for the standard deviation of proportions. The above sample size applies to all variables except Intensity which has 3535 cases. 
Table 2. Regression Results, Dependent Variable ln (Hourly Wage)

\begin{tabular}{|c|c|c|c|c|c|}
\hline Variable & I & II & III & IV & $\mathrm{V}$ \\
\hline Computer & $\begin{array}{c}0.178 \\
(13.72)\end{array}$ & $\begin{array}{l}0.174 \\
(13.42)\end{array}$ & $\begin{array}{c}0.138 \\
(7.60)\end{array}$ & $\begin{array}{c}0.070 \\
(4.01)\end{array}$ & - \\
\hline Tools & - & $\begin{array}{r}-0.031 \\
(2.61)\end{array}$ & $\begin{array}{r}-0.031 \\
(2.89)\end{array}$ & $\begin{array}{r}-0.003 \\
(0.23)\end{array}$ & $\begin{array}{r}-0.006 \\
(0.54)\end{array}$ \\
\hline Compbtr & & - & $\begin{array}{l}0.050 \\
(2.89)\end{array}$ & $\begin{array}{l}0.031 \\
(1.91)\end{array}$ & - \\
\hline Intensity & & - & - & - & $\begin{array}{l}0.058 \\
(2.89)\end{array}$ \\
\hline Other Controls & $\begin{array}{l}\text { Education } \\
\text { Tenure } \\
\text { Tenure }^{2} \\
\text { Married } \\
\text { R7, M7 } \\
\text { Union } \\
\text { Fulltime } \\
\text { Writegood } \\
\text { Speakgood } \\
\text { Sex, Race } \\
\text { Private } \\
\text { Region }\end{array}$ & As I & As I & $\begin{array}{l}\text { As I } \\
\quad+ \\
\text { Industry } \\
\text { Firm Size } \\
\text { Occupation }\end{array}$ & $\begin{array}{l}\text { As IV } \\
\text { n }\end{array}$ \\
\hline $\begin{array}{l}\text { R-Squared } \\
\mathrm{N}\end{array}$ & $\begin{array}{l}0.516 \\
3572\end{array}$ & $\begin{array}{l}0.517 \\
3572\end{array}$ & $\begin{array}{l}0.518 \\
3572\end{array}$ & $\begin{array}{l}0.593 \\
3572\end{array}$ & $\begin{array}{l}0.589 \\
3535\end{array}$ \\
\hline
\end{tabular}


Table 3. Regression Results, Full Time Workers Only, Dependent Variable $\ln$ (Hourly Wage)

\begin{tabular}{|c|c|c|c|c|c|}
\hline Variable & $\mathrm{I}$ & II & III & IV & V \\
\hline Computer & $\begin{array}{c}0.171 \\
(11.73)\end{array}$ & $\begin{array}{l}0.165 \\
(11.26)\end{array}$ & $\begin{array}{c}0.123 \\
(6.17)\end{array}$ & $\begin{array}{c}0.070 \\
(3.63)\end{array}$ & - \\
\hline Tools & - & $\begin{array}{l}-0.049 \\
(3.68)\end{array}$ & $\begin{array}{r}-0.049 \\
(3.70)\end{array}$ & $\begin{array}{r}-0.014 \\
(1.06)\end{array}$ & $\begin{array}{r}-0.012 \\
(0.94)\end{array}$ \\
\hline Compbtr & & - & $\begin{array}{c}0.057 \\
(3.05)\end{array}$ & $\begin{array}{c}0.034 \\
(1.97)\end{array}$ & - \\
\hline Intensity & - & - & - & - & $\begin{array}{l}0.045 \\
(1.99) \\
\end{array}$ \\
\hline Other Controls & $\begin{array}{l}\text { Education } \\
\text { Tenure } \\
\text { Tenure }^{2} \\
\text { Married } \\
\text { R7, M7 } \\
\text { Union } \\
\text { Writegood } \\
\text { Speakgood } \\
\text { Sex, Race } \\
\text { Private } \\
\text { Region }\end{array}$ & As I & As I & $\begin{array}{l}\text { As I } \\
\quad+ \\
\text { Industry } \\
\text { Firm Size } \\
\text { Occupation }\end{array}$ & $\begin{array}{l}\text { As IV } \\
\text { n }\end{array}$ \\
\hline $\begin{array}{l}\text { R-Squared } \\
\mathrm{N}\end{array}$ & $\begin{array}{l}0.398 \\
2834\end{array}$ & $\begin{array}{l}0.401 \\
2834\end{array}$ & $\begin{array}{l}0.403 \\
2834\end{array}$ & $\begin{array}{l}0.495 \\
2834\end{array}$ & $\begin{array}{l}0.489 \\
2801\end{array}$ \\
\hline
\end{tabular}

